\section{ЛІТЕРАТУРА}

1. Воловик П. М. Теорія імовірностей і математична статистика в педагогіці. Київ, 1969. 222 с

2. Гончаренко С. У. Педагогічні дослідження : Методологічні поради молодим науковцям. Київ; Вінниця, 2008. $278 \mathrm{c.}$

3. Загвязинский В., Атаханов Р. Методология и методы психолого-педагогического исследования : учеб. пособие для студ. высш. пед. учеб. заведений ; 4е изд. Москва, 2006. 208 с.

4. Методы системного педагогического исследования : учеб. пособие / под ред. Н. В. Кузьминой. Ленинград, 1980. $172 \mathrm{c}$

5. Образцов П. И. Методы и методология психологопедагогического исследования. Санкт-Петербург, 2004. $268 \mathrm{c}$

6. Сисоєва С. О., Кристопчук Т. Є. Педагогічний експеримент у наукових дослідженнях неперервної професійної освіти : навч.-метод. посіб. Луцьк, 2009. $460 \mathrm{c}$

\section{REFERENCES}

1. Volovyk, P. M. (1969). Teoriia imovirnostei $i$ matematychna statystyka $v$ pedahohitsi [Theory of probabilities and mathematical statistics in pedagogy]. Kyiv, 222 p. [in Ukrainian].
2. Honcharenko, S. U. (2008). Pedahohichni doslidzhennia : Metodolohichni porady molodym naukovtsiam [Pedagogical research: Methodological advice for young scientists]. Kyiv; Vinnytsia, 278 p. [in Ukrainian].

3. Zagvyazinskiy, V. \& Atahanov, R. (2006). Metodologiya i metodyi psihologo-pedagogicheskogo issledovaniya : ucheb. posobie dlya stud. vyissh. ped. ucheb. zavedeniy; 4-e izd [Methodology and methods of psychological and pedagogical research : Tutorial for higher school students]. Moscov, $208 \mathrm{p}$. [in Russian]

4. Kuzmina, N. V. (Ed.). (1980). Metodyi sistemnogo pedagogicheskogo issledovaniya : ucheb. posobie [Methods of systematic pedagogical research : Tutorial]. Leningrad, 172 p. [in Russian].

5. Obraztsov, P. I. (2004). Metodyi i metodologiya psihologo-pedagogicheskogo issledovaniya [Methods and methodology of psycho-pedagogical research]. SanktPeterburg, 268 p. [in Russian].

6. Sysoieva, S. O. \& Krystopchuk, T. Ye. (2009). Pedahohichnyi eksperyment $u$ naukovykh doslidzhenniakh neperervnoi profesiinoi osvity: navch.metod. posib. [Pedagogical experiment in scientific researches of continuous vocational education : Manual]. Lutsk, 460 p. [in Ukrainian].

Стаття надійшла до редакції 11.04.2019

УДК 37.013:001.89(045)

DOI:

Тетяна Гуркова, старший викладач кафедри початкової освіти Комунальний заклад "Запорізький обласний інститут післядипломної педагогічної освіти” Запорізької обласної ради

\title{
ДЕФІНІЦІЇ ПОНЯТЬ “ОСВІТНІЙ ПРОСТІР”, “СЕРЕДОВИЩЕ”, “ОСВІТНС СЕРЕДОВИЩЕ”
}

У статті представлено сутність понять “освітній простір”, “середовище”, “освітнє середовище”. Узагальнено результати аналізу різних наукових позицій щзоо трактування смислу досліджуваних феноменів. Окреслено основні смислові відмінності циих педагогічних конструктів. Наголошено на їх багатовимірності й різноплановості. 3'ясовно, що термін “освітнє середовище” є одним із ключових психолого-педагогічних понять. Простежено історичні зміни в змісті освітнього середовища, які були започатковані видатними педагогами.

Ключові слова: освітній простір; середовище; освітнє середовище.

Jim. 14.

Tetyana Hurkova, Senior Lecturer of the Primary Education Department Municipal Institution "Zaporizhzhya Regional Institute Postgraduate Pedagogical Education” Zaporizhzhya Regional Council

\section{DEFINITION OFTHE CONCEPTS “EDUCATIONAL SPACE”, "ENVIRONMENT", "EDUCATIONAL ENVIRONMENT"}

The article is devoted to research of different approaches to the interpretation of the concepts: "an educational space", "an environment", "and an educational environment". It has been found out that in the psychological and pedagogical theory and practice there is no single understanding concerning the interpretation of these terms, there is any established perception of them.

On the basis of the analysis, the essence of the concepts "an educational space", "an environment", "an 
educational environment" is established. The author studies the category of "educational space". The results of the comparative analysis of the essence of the concepts "an environment" and "an educational space" are presented. Their precondition and interdependence are investigated. It is determined that the environment reflects the interconnection of conditions, ensures human development, involves mutual influence, interaction of the environment with the subject, and space can exist without a person. Space relative to the environment is a construct of higher order, which may contain several environments.

The particular attention is alloted to defining the essence of the definition of "an educational environment". The phenomenon of the educational environment is substantiated; existence of several types of them is established. Multidimensionality and versatility of consideration of the investigated phenomenon by different authors were revealed. It turns out that the term "an educational environment" is one of the key of the psychological and pedagogical concepts. The historical changes in the contents of the educational environment, which were initiated by outstanding teachers, were traced, respectively, and in the formation of certain requirements for its creation. The structural components of the educational environment are singled out. It is stated that during the creation of a modern educational environment it is necessary to take into account the theory of child development and the requirements for a modern teacher.

Keywords: an educational space; an environment; an educational environment

П остановка проблеми. У Законі “Про освіту”, Концепції Нової української школи, професійному стандарті вчителя початкових класів закладу загальної середньої освіти, Державному стандарті початкової освіти в широкому соціокультурному контексті сьогодні розглядається формування ключових компетентностей, необхідних кожній сучасній людині для успішної життедіяльності.

Основою цього процесу слугує наявність ефективного освітнього простору, уміння вчителя початкових класів створити сучасне освітнє середовище, комфортне для всіх учасників процесу навчання.

У такому середовищі,де зростає, розвивається, формується особистість стає можливим зміщення акценту 3 діяльності вчителя на діяльність учня, його самонавчання, саморозвиток, взаємодію $з$ іншими учасниками освітнього процесу.

Мета статті полягає в аналізі існуючих підходів до трактування понять “освітній простір", "середовище", “освітнє середовище" та 3'ясування взаємозалежностей між ними.

Важливим для нашого дослідження $є$ розуміння сугності поняття “освітній простір”. Як предмет наукових досліджень цей конструкт перебуває в центрі уваги вітчизняних і зарубіжних вчених (Н. Бастун, С. Бондирева, О. Веряєв, С. Гершунський, В. Гинецінський, Б. Ельконін, О. Леонова, Н. Рибка, А. Самодрин, В. Слободчиков, Т. Ткач, І. Фрумін, T. Чернецька, I. Шалаєв, I. Шендрик, Г. Щевельова та ін.).

Як можливість, що дозволяє особистості задовольнити свої освітні потреби, вибрати в ньому індивідуальний маршрут для здобуття освіти на різних стадіях свого розвитку розглядає освітній простір Е. Скибицький. Термін “освітній простір” він трактує як безліч об'єктів, між якими встановлені відносини. На його думку, освітній простір повинен буги організований як сукупність освітніх систем, причому кожній з них відводиться певне місце, обумовлене складовими і функціями самої освітньої системи та іншими факторами [7, 186 - 196].

Інакше сутність поняття "освітній простір" розкриває А. Цимбалару Науковець пояснює цей феномен як певну частку соціуму, де створено умови для розвитку особистості та можливість $\mathrm{i}$ наявність формування особистісного простору суб'єкта освітнього процесу. Проведене теоретичне дослідження автора дає підстави для певних висновків про те, що освітній простір розглядається стосовно особистості, оскільки лише їй притаманна діяльність, завдяки якій освоюється освітнє середовище. А. Цимбалару окреслює основні аспекти встановлення смислового поля поняття "освітній простір", виявляє його структури і механізми формування, зважаючи на сучасний контекст розуміння $[13,41$ $-50]$.

Інколи науковці ототожнюють поняття “освітній простір” і “середовище”. Середовище, на їх думку, $є$ зовнішнім простором, що оточує об'єкт дослідження, має системно організовані складові та створює умови для існування його у просторі, вступаючи з ним у взаємодію. Розглядаючи поняття "простір" і "середовище", науковці визначають їх як близькі за значенням, але не синонімічні. Середовище відображає взаємозв' язок умов, що забезпечують розвиток людини. У цьому випадку передбачається присутність людини в середовищі, взаємовплив, взаємодія оточення з суб'єктом, а простір може існувати без людини. Простір по відношенню до середовища $\epsilon$ конструктом вищого порядку, в якому може знаходитися декілька середовищ [1].

Отже, розуміння сутності поняття "середовище" $є$ важливим для нашого дослідження. 


\section{ДЕФІНШЩЇПОНЯТЬ “ОСВІТНІЙПРОСТІР”, “СЕРЕДОВИЩЕ”, “ОСВІТНЕ СЕРЕДОВИЩЕ”}

У тлумачних словниках термін “середовище" розглядається як: оточення, сукупність природних умов, у яких відбувається життєдіяльність якогонебудь організму [11, 429; 12,745$]$; наповненість просторово-наочного, природного і соціального оточення людини, причому акцентується увага на тому, що несприятливе оточення не дає можливості особистості зростати та розвиватися [10, 759].

Означене поняття у педагогічних словниках відсутнє. А в словнику з соціальної педагогіки дефініцію “середовище” розкрито як соціальнопобутові умови, що оточують людину, обстановка, а також люди, пов'язані з ним спільністю цих умов [8, 294].

Середовище як сукупність умов та впливів, що оточують людину, можливість для ії розвитку, які містяться в соціальномуі просторово-предметному оточенні розглядає Д. Маркович [6].

По-іншому трактує поняття "середовище" О. Савченко. На іiї думку, це життєвий простір школяра, який впливає на його свідомість, почуття, вчинки. Науковець підкреслює унікальну можливість закладів освіти створювати власний дизайн середовища внаслідок одержання свободи розвитку, сприятливих умов для партнерства, соціальної компетентності вчителів та учнів $[9,74]$.

Останні роки поняття “середовище”, яке постійно перебуває в полі інтересів вітчизняних і зарубіжних науковців, уточнюється ознакою “освітнє”. Феномен “освітнє середовище” розуміють як систему впливів й умов формування особистості за заданим зразком, а також можливостей для iï розвитку, що містяться в соціальному і просторово-предметному оточенні. Спостерігаємо багатовимірність і різноплановість розгляду досліджуваного феномену різними авторами. Наприклад, під освітнім середовищем А. Веряєв, В. Козирєв, І. Шалаєв розуміють сукупність установлених в освітньому процесі організаційно-педагогічних умов і матеріальних, просторово-предметних факторів, а також соціальних компонентів і міжособистісних відносин, що впливають на формування особистості із заданими якостями. Ці фактори взаємопов'язані, доповнюють, збагачують один одного та впливають на кожного суб'єкта, тому освітнє середовище з позиції цих авторів $€$ процес функціонування конкретного закладу освіти. На їх думку, освітнє середовище це складна система, що акумулює інтелектуальні, культурні, програмно-методичні, організаційні та технічні ресурси і забезпечує формування особистості в їі різноманітних проявах [14].

Схожу думку щодо сутності поняття “освітнє середовище” висловлює О. Артюхіна. Вона доводить, що існує декілька типів освітніх середовищ, які необхідно розглядати як цілісне явище, оскільки вони одночасно, взаємно проникають і взаємодіють між собою, взаємозбагачують один одного:

- середовище, що орієнтоване на створення умов для розвитку особистісних якостей: здоров'язбережувальне, культуротворче, те, що розвиває естетично розвивальне, середовище становлення морального досвіду, середовище розвитку і саморозвитку особистості тощо;

- середовище, що орієнтоване на створення умов для формування професійної спрямованості, тобто сукупності професійно значущих якостей, а отже мають професійно-освітні функції: інформаційно-освітнє середовище закладу вищої освіти, інформаційне, професійно-освітнє, віртуальне освітнє середовище тощо;

- середовище, що орієнтоване на професійний та особистісний розвиток і саморозвиток усіх учасників освітнього процесу (середовище професійно-особистісногосаморозвиткустудентів) [1].

Поняття “освітнє середовище” - одне 3 ключових психолого-педагогічних понять. У цьому контексті особливо важливі виявлені психологами основні потреби й можливості розвитку, які забезпечують задоволення фізіологічних потреб; потреб у безпеці; потреб у засвоєнні групових норм і ідеалів; в любові, пошані, визнанні, суспільному схваленні; потреби в праці, значущій діяльності; потреби в збереженні і підвищенні самооцінки: пізнавальної потреби в особливій галузі інтересів; потреби в естетичному оформленні навколишнього оточення; потреби в самостійному впорядкуванні індивідуальної картини світу; потреби в оволодінні певним рівнем майстерності; потребі в самоактуалізації особистості.

Смисловим поняттям “освітнього середовища", за визначенням Н. Гонтаровської, є сукупність об'єктивних зовнішніх умов, факторів, соціальних об'єктів, необхідних для успішного функціонування освіти. Це система впливів і умов формування особистості, а також можливостей для iï розвитку, які містяться в соціальному і просторово-предметному оточенні [2].

У більшості зарубіжних досліджень освітнє середовище описується в значенні “ефективності школи” як соціальної системи - емоційного клімату, особистого благополуччя, особливостей мікрокультури, якості виховного освітнього процесу.

Великі зміни в змісті освітнього середовища були започатковані Д. Локком, Й. Песталоцці, 
Ж. Руссо. В освітніх системах, створених ними, учень займав пасивну позицію, його інтерес формувався вчителем, основний пріоритет авторитет вчителя Ще за часів Платона склалися певні вимоги до освітнього середовища. Деякі 3 цих вимог і структурних компонентів актуальні й сьогодні. Наприклад, Г. Ковальов виокремлює структурні компоненти освітнього середовища такі як:

- фізичне оточення - шкільне приміщення, його дизайн, розмір та просторова структура навчальних помешкань, умови для переміщення і розміщення учнів;

- людський фактор - добір учнів, наповнення класів та його вплив на соціальну поведінку учнів, особливості й успішність учнів, етнічні особливості, якість підготовки вчителів, статевовікова структура шкільного контингенту;

- програма навчання - новаторський характер змісту програм навчання, технології навчання, стиль та методи навчання, форми навчальної діяльності, характер контролю [3].

Виділяють основні типи освітнього середовища (за Я. Корчаком):

- догматичне освітнє середовище - сприяє розвитку пасивності та залежності дитини;

- кар'єрне освітнє середовище - сприяє розвитку активності та залежності дитини;

- безтурботне освітнє середовище - сприяє вільному розвитку і зумовлює пасивну життєву позицію дитини;

- творче освітнє середовище - сприяє вільному розвитку активної дитини [5].

Останнє, на нашу думку, вдало корелюється 3 викликами сучасності. Освітнє середовище Нової української школи має відображати філософію Концепції НУШта відповідати вимогам: безпечне, належати дитині, мати вільний доступ, забезпечувати потреби дитини, мати баланс: навчання - гра - відпочинок, а також дитина вчитель, надавати дитині право вибору, усвідомлюючи наслідки, мати дороговкази: цінності, правила [4].

Висновок. Виходячи з вищезазначеного, констатуємо, що, плануючи організацію освітнього середовища, необхідно брати до уваги теорію розвитку дитини (Е. Еріксон, Ж. Піаже та ін.) в паралелі з сучасними вимогами до вчителя початкових класів. Вчителі повинні звертати увагу на особливості організації та управління класом, розвиток навичок XXI століття та певних якостей дітей (працьовитість, ініціативність, довіра, вміння вчитися, участь у моделюванні спільних правил і цінностей, співпраця, робота в команді, повага, відповідальність та успішність тощо). Цьому, безперечно, сприятиме ефективне освітнє середовище, в якому можлива співпраця вчителя й учнів, партнерство, спільний процес пізнання і відкриттів, постійне створення ситуації успіху.

Таким чином, проведений нами аналіз існуючих підходів засвідчив відсутність єдиного розуміння щодо трактування понять “освітній простір”, “середовище”, “освітнє середовище” та 3'ясування взаємозалежностей між ними.

Здійснений нами теоретичний аналіз не вичерпує всіх аспектів окресленої теми і закладає основу для подальшого дослідження.

\section{ЛІТЕРАТУРА}

1. Артюхина А. И. Образовательная среда высшего учебного заведения как педагогический феномен: Монография. Волгоград. 2006. 237 с.

2. Гонтаровська Н. В., Теоретичні та методичні засади створення освітнього середовища як фактору розвитку особистості школяра. Київ. 2012 р.

3. Ковалев Г. А. Психическое розвитие ребёнка и жизненная среда. Москва. 1993. 130 с.

4. Концепція Нової української школи. URL: http://ru.osvita.ua/legislation/Ser_osv/54258/

5. Крижко В. В., Мамаєва І. О. Аксіологічний потенціал державного управління освітою: навчальний посібник. Київ. 2005. 217 с.

6. Маркович Д. Ж. Соціальна екологія. Москва. 1991.

7. Скибицкий Э. Г., Артюшкин О. В. О соотношении понятий “информационнообразовательное пространство” и “информационнообразовательная среда". Сибирский педагогический журнал. 2007. № 14. С. 186-196.

8. Словарь по социальной педагогике: Учебн.пособие для студ. высш. учебн. заведений / Авт.- сост. Л. В. Мардахаев. Москва. 2002. С. 294.

9. Савченко О.Я. Виховний потенціал початкової освіти: посібник для вчителів і методистів початкового навчання. 3-є вид., без змін. Київ. 226 с.

10. Толковый словарь русского языка / С. И. Ожегов, Н. Ю. Шведова. Москва. 1997. $944 \mathrm{c}$.

11. Тлумачний словник української мови/Худож. - оформлювач І. В. Осипов. Харків, 2008. С. 429

12. Тлумачний словник української мови: Понад 12500 статей (близько 40000 слів)/Зад ред.. д-ра філологічних наук, проф.. В. С. Калашника. Харків. 2002. С. 745

13. Український педагогічний словник С. У. Гончаренко. Довідкове видування видавництво “Либідь” при Київському університеті. Київ. $10-375$ с.

14. Цимбалару А. Д. Освітній простір: 
сутність, структура і механізми створення / Український педагогічний журнал. 2016. №1. C. $41-50$.

15. Шалаев И. К., Веряев А. А. От образовательных сред к образовательному пространству: понятие, формирование, свойства. Педагог. 1998. № 4. URL: http://www.uni-altai.ru/Journal/pedagog/ pedagog 4/articl_1.html.

\section{REFERENCES}

1. Artyukhina, A. I. (2006). Obrazovatelnaya sreda vysshego uchebnogo zavedeniya kak pedagogicheskiy fenomen : Monografiya [Educational environment of a higher educational institution as a pedagogical phenomenon : Monograph]. Volgograd, 237 p. [in Russian].

2. Hontarovska, N.V. (2012). Teoretychni ta metodychni zasady stvorennia osvitnoho seredovyshcha yak faktoru rozvytku osobystosti shkoliara [Theoretical and methodical principles of creating an educational environment as a factor in the development of a student's personality]. Kyiv. [in Ukrainian].

3. Kovalev, G. A. (1993). Psikhicheskoe rozvitie rebenka $i$ zhiznennaya sreda [Mental development of the child and life environment]. Moscov, $130 \mathrm{p}$. [in Russian].

4. Kontseptsiia Novoi ukrainskoi shkoly [Concept of the New Ukrainian School]. Available at: http:// ru.osvita.ua/legislation/Ser_osv/ 54258/ [in Ukrainian].

5. Kryzhko, V. V. \& Mamaieva, I. O. (2005). Aksiolohichnyi potentsial derzhavnoho upravlinnia osvitoiu: navchalnyi posibnyk [Axiological potential of state education management: a manual]. Kyiv, 217 p. [in Ukrainian].

6. Markovych, D. Zh. (1991). Sotsialna ekolohiia [Social ecology]. [in Ukrainian].

7. Skibitskiy, E. G. \& Artyushkin, O. V. (2007). O sootnoshenii ponyatiy "informatsionnoobrazovatelnoe prostranstvo" i "informatsionno- obrazovatelnaya sreda" [On the relationship between the concepts "an information and educational space" and "an informationand educational environment"]. Siberian Pedagogical Journal. No. 14, pp.186-196. [in Russian].

8. Slovar po sotsialnoy pedagogike: uchebn.posobie dlya stud. (2002). [Dictionary on social pedagogy]. (Ed.). L.V.Mardakhaev. Moscov, p. 294. [in Russian].

9. Savchenko, O.Ia., Vykhovnyi potentsial pochatkovoi osvity: posibnyk dlia vchyteliv $i$ metodystiv pochatkovoho navchannia [Educational potential of elementary education: a manual for teachers and methodologists of elementary education]. Kyiv, 226 p. [in Ukrainian].

10. Ozhegov, S. I. \& Shvedova, N. Yu. (1997). Tolkovyy slovar russkogo yazyka [Intelligent dictionary of the Russian language]. Moscov, 944 p. [in Russian].

11. Tlumachnyi slovnyk ukrainskoi movy (2008). [Interpretative dictionary of the Ukrainian language]. Kharkiv, p. 429. [in Ukrainian].

12. Tlumachnyi slovnyk ukrainskoi movy (2002). [Interpretative dictionary of the Ukrainian language]. (Ed.). V.S.Kalashnyk. Kharkiv, p. 745. [in Ukrainian].

13. Ukrainskyi pedahohichnyi slovnyk [Ukrainian Pedagogical Dictionary]. (Ed.). S. U. Honcharenko. Publishing house "Lybid" at the Kyiv University, Kyiv, pp. 10 - 375. [in Ukrainian].

14. Tsymbalaru, A. D. (2016). Osvitnii prostir: sutnist, struktura i mekhanizmy stvorennia [Educational space : the essence, structure and mechanisms of creation]. Ukrainian Pedagogical Journal. No.1, pp. 41-50. [in Ukrainian].

15. Shalaev, I. K. \& Veryaev, A. A. (1998). Ot obrazovatelnykh sred k obrazovatelnomu prostranstvu: ponyatie, formirovanie, svoystva [From educational media to educational space: concept, formation, properties]. [Electronic resource]. A pedagogue, No. 4. Available at: http://www.unialtai.ru/Journal/pedagog/ pedagog 4/articl 1.html. [in Russian].

Стаття надійшла до редакції 15.03.2019

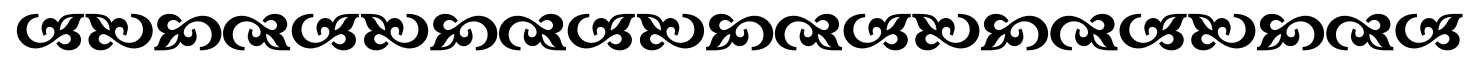

“Вченість - ие солодкий плід гіркого кореня”.

$$
\begin{array}{r}
\text { Iсоқрат } \\
\text { давнъогрецький боілособб }
\end{array}
$$

“Вивчай все не з марнославства, а задля прақтичної қористі”.

Теорг Крістоб Аіхтенберг

німецький вчений

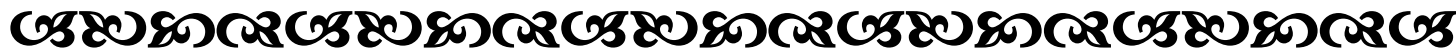

